\title{
Genomic Typing of Enterococci Isolated from Bovine Mammary Glands and Environmental Sources ${ }^{1}$
}

\author{
C. S. Petersson-Wolfe, S. Adams, S. L. Wolf, and J. S. Hogan ${ }^{2}$ \\ Department of Animal Sciences, The Ohio State University, Ohio Agricultural Research and Development Center, Wooster, 44691
}

\begin{abstract}
Enterococcal isolates $(n=102)$ from various sources of bovine origin on 1 farm were characterized using pulsed field gel electrophoresis analysis of $\mathrm{SmaI}$ restriction patterns. Isolates originated from feed samples $(\mathrm{n}=$ $6)$, bedding samples $(\mathrm{n}=15)$, and bovine quarter-milk samples $(\mathrm{n}=81)$. Isolates collected from milk samples included those from high-somatic cell count cows ( $\mathrm{n}=$ $42)$, postpartum milk samples $(n=16)$, and clinical mastitis samples $(\mathrm{n}=23)$. Species evaluated included Enterococcus faecium ( $\mathrm{n}=68)$, Enterococcus casseliflavus $(\mathrm{n}=29)$, and Enterococcus faecalis $(\mathrm{n}=5)$. A total of 20 clusters representing 44 isolates were detected when a similarity cut-off level of $75 \%$ was applied to interpret the pulsed field gel electrophoresis results. Fifteen of the clusters contained only isolates from milk samples. Four clusters contained isolates from bedding and milk samples. One cluster contained only isolates from feed samples. Clusters comprised of a single species represented 17 of the 20 total clusters. These results suggest enterococci from bovine origin were genetically diverse, whereas a limited number of isolates from various sources appeared to cluster together.

Key words: Enterococcus species, mammary, epidemiology
\end{abstract}

\section{INTRODUCTION}

Enterococcus spp. have commonly been included in the heterogeneous grouping of environmental streptococci or non-agalactiae streptococci when rate or prevalence of naturally occurring IMI have been reported for individual herds or survey results (Hogan et al., 1989; Gonzalez et al., 1990). Although enterococcal mastitis is relatively uncommon compared with subclinical and clinical mastitis caused by Streptococcus spp., milk

Received April 2, 2007.

Accepted October 18, 2007.

${ }^{1}$ Salaries and research support were provided by state and federal funds appropriated to the Ohio Agricultural Research and Development Center, The Ohio State University 29-07AS.

${ }^{2}$ Corresponding author: hogan.4@osu.edu quality and udder health problems within herds caused by enterococcal IMI have been documented (Todhunter et al., 1995). A concern about enterococci in the environment of the cow relates to the emerging prominence of nosocomial infections caused by enterococci, prevalence of resistance among these bacteria to commonly used antibiotics, and the shared virulence traits expressed by isolates from hospital patients and isolates from food animals (Mannu et al., 2003).

The epidemiology of IMI caused by Enterococcus spp. is relatively undefined with regards to common farm management practices that may lead to the control of mastitis caused by these organisms. The use of pulsed field gel electrophoresis (PFGE) to compare restriction fragments of DNA among bovine isolates has been valuable in determining the epidemiological traits of Staphylococcus aureus (Zadoks et al., 2000; Middleton et al., 2002) and Streptococcus uberis (Douglas et al., 2000; McDougall et al., 2004) isolated from bovine mastitis. Similarly, comparison of PFGE patterns of isolates from nosocomial infections are common to determine if hospital outbreaks with enterococci are from a single clone or multiple strains (Baldassarri et al., 2005). Comparison of enterococci isolated from milk with isolates in the environment may provide insight into the epidemiology of enterococcal mastitis on a dairy farm. The purpose of the current study was to use PFGE to compare genetic similarity among restriction endonuclease patterns for enterococci isolated from quarter-milk samples, forage, and bedding of a commercial dairy.

\section{MATERIALS AND METHODS}

\section{Origin of Isolates}

The survey herd consisted of approximately 1,200 lactating cows managed in dry lot corrals and fed a green chop alfalfa-based diet. The herd was selected based on reports by extension personnel of milk quality problems due to enterococci. A total of 102 enterococcal isolates were collected from the dairy herd during April 2004 to October 2004 for PFGE analysis. The distribution of the 102 isolates tested by bacterial species and source are in Table 1. 
Table 1. Distribution of enterococci isolated from mammary secretions and the environment of a commercial dairy farm

\begin{tabular}{lccc}
\hline & \multicolumn{3}{c}{ Enterococcus species } \\
\cline { 2 - 4 } & $\begin{array}{c}\text { Enterococcus } \\
\text { faecium } \\
(\mathrm{n}=68)\end{array}$ & $\begin{array}{c}\text { Enterococcus } \\
\text { casseliflavus } \\
(\mathrm{n}=29)\end{array}$ & $\begin{array}{c}\text { Enterococcus } \\
\text { faecalis } \\
(\mathrm{n}=5)\end{array}$ \\
\hline Origin of isolates & 28 & 14 & 0 \\
Mammary $^{1}(\mathrm{n}=81)$ & 9 & 5 & 2 \\
High SCC $_{\text {Postpartum }}$ & 21 & 1 & 1 \\
Clinical mastitis $_{\text {Environment }(\mathrm{n}=21)}$ & 6 & 9 & 0 \\
Bedding & 4 & 0 & 2 \\
Feed & & & \\
\hline
\end{tabular}

${ }^{1}$ Isolates of mammary origin were from quarter-milk samples collected using aseptic technique from high-SCC milk within 2 wk after DHI testing (high SCC), mammary quarters with clinical mastitis before antibiotic therapy (clinical mastitis), and cows within $3 \mathrm{~d}$ after parturition (postpartum).

\section{Milk Samples}

Isolates of mammary origin were from quarter-milk samples collected using aseptic technique from highSCC milk within 2 wk after DHI testing ( $\mathrm{n}=1,368)$, mammary quarters with clinical mastitis before antibiotic therapy $(\mathrm{n}=453)$, and cows within $3 \mathrm{~d}$ after parturition $(\mathrm{n}=3,162)$. All milk samples were frozen at $-20^{\circ} \mathrm{C}$ after collection and thawed at room temperature before primary isolation of bacteria. Milk was plated on tryptic soy agar (Becton, Dickinson and Company, Sparks, MD) containing $5 \%$ bovine blood and $0.1 \%$ esculin (MP Biomedicals LLC, Aurora, OH). Primary isolation plates were incubated aerobically at $37^{\circ} \mathrm{C}$ for $48 \mathrm{~h}$. Grampositive, catalase-negative cocci that hydrolyzed esculin and grew in the presence of $6.5 \% \mathrm{NaCl}$ were presumptively identified as enterococci (NMC, 1999). The number of isolates presumptively identified as enterococci were 42 from SCC milk, 23 from clinical mastitis, and 16 from postpartum milk. Isolates presumptively identified as enterococci and subsequently identified as an Enterococcus spp. by the API 20 STREP system (bioMérieux Industry, Hazelwood, MO) with greater than 95\% confidence were included for testing. If enterococci were isolated from a mammary quarter multiple times during the survey, only the isolate from the initial sample was tested by PFGE.

\section{Bedding and Feed}

Twenty-five grams of composite-dried manure bedding sample was collected monthly from locations in lactating cow corrals $(\mathrm{n}=12)$ during the survey period. Twenty-five grams of green chop alfalfa, sampled after harvest and before mixing into the diet of lactating cows, was collected twice $(n=4)$ during the last month of the survey. Bacteria were isolated in bedding and feed by adding $10 \mathrm{~g}$ of sample to $90 \mathrm{~mL}$ of sterile PBS and mixing the solution for $40 \mathrm{~s}$ in a stomacher (Stomacher Lab-Blender 400, Tekmar Co., Cincinnati, OH). Serial dilutions of the liquid phase in sterile PBS were plated on the surface of kanamycin $(20 \mathrm{mg} / \mathrm{L})$ esculin azide agar (Oxoid Ltd., Basingstoke, Hampshire, UK) for selection and differentiation of enterococci. Serial dilutions plated were $1: 10^{2}$ to $1: 10^{6}$. Inoculated plates were incubated $24 \mathrm{~h}$ at $37^{\circ} \mathrm{C}$. Random colonies with black pigment and halos of esculin hydrolysis were selected and plated on trypticase soy agar containing 5\% bovine blood and $0.1 \%$ esculin. Presumptive identification and testing with the API 20 STREP system were the same as isolates from milk samples. To reduce possible repetition of clones, a single isolate of each species identified from randomly selected colonies of each bedding sample was included in PFGE testing. Each of the isolates collected from forage and subsequently identified as Enterococcus spp. were included in PFGE analysis.

\section{PFGE}

Genomic DNA was prepared using a previously described method (Saeedi et al., 2002). Restriction digestion of bacteria DNA was carried out using 40 units of SmaI (New England Biolabs, Ipswich, MA) in individual digestion tubes $\left(25^{\circ} \mathrm{C}, 4 \mathrm{~h}\right)$. The PFGE was performed on a Chef Mapper (BioRad, Hercules, CA) in $0.5 \times$ Tris-borate EDTA (TBE) running buffer (0.9 $M$ Tris base, $0.9 M$ boric acid, $0.02 M$ EDTA, $\mathrm{pH}$ 8.0) with recirculation at $14^{\circ} \mathrm{C}$. The DNA restriction fragments were resolved in $1.0 \%$ SeaKem Gold agarose (Cambrex, East Rutherford, NJ) in $0.5 \times$ TBE buffer. Lambda ladder (BioRad) was used as a size marker on each gel. Electrophoresis was carried out at $6 \mathrm{~V} / \mathrm{cm}$ for $14 \mathrm{~h}$ with pulse timed of $2.16 \mathrm{~s}$ to $35.07 \mathrm{~s}$ (linear ramping) with a $120^{\circ}$ angle. Gels were stained with ethidium bromide and viewed with UV illumination. Gel images were saved in the TIFF format and exported to the Fingerprinted Informatix II software (BioRad). Data were analyzed using the Dice coefficient-unweighted pair-group method with arithmetic averages with $1.0 \%$ band tolerance and $1.0 \%$ optimization setting for the whole profile. A dendrogram was generated to examine relatedness of PFGE profiles for all study isolates. Similarity cutoff value of $75 \%$ was applied (Seong et al., 2004).

\section{RESULTS}

Pulsed field gel electrophoresis analysis of SmaI restriction patterns determined banding patterns ranged among isolates from 9 to 20 fragments with a range in size from 20 to $250 \mathrm{~kb}$. Using a similarity cut-off value 
of $75 \%, 44$ of the isolates were classified into 20 clusters, whereas 58 isolates had separate positions in the dendrogram (Figure 1). Percentages of isolates by species that were not clustered with other isolates were $56.5 \%$ Enterococcus faecium, $64.3 \%$ Enterococcus casseliflavus, and $60.0 \%$ Enterococcus faecalis. Percentages of isolates by origin that were not clustered with other isolates were $54.8 \%$ of isolates from high-SCC quarters, $43.4 \%$ of isolates from clinical mastitis, $75.0 \%$ of isolates from postpartum glands, $73.0 \%$ of bedding isolates, and $33.0 \%$ of isolates from feed samples.

The number of isolates within each cluster ranged from 2 to 4 (Table 2). Clusters comprising a single species represented 17 of the 20 total clusters. Of the 20 clusters, 15 contained only isolates from milk. Isolates within 10 clusters originated from mammary glands of the same physiological state (high SCC, postpartum, or clinical mastitis). Two of the clusters contained only isolates collected from different quarters of the same cow. The physiological state of the gland from which the mammary isolates were collected differed within 5 clusters. Four clusters contained isolates from both bedding and milk. Two of these clusters contained $E$. casseliflavus from bedding and E. faecium isolated from clinical glands. Isolates from bedding samples did not cluster together. A single cluster comprised $4 E$. faecium isolates from feed samples. Isolates from feed samples did not cluster with isolates from bedding or those of mammary origin.

\section{DISCUSSION}

Enterococcal isolates of bovine and environmental origin within a single dairy herd were genetically diverse. The majority of isolates of each species and from most sources did not cluster with any other isolates tested. Tenover et al. (1995) suggested PFGE be used to study epidemiological characteristics during a bacterial disease outbreak within a community spanning a period of less than a year. The current study was designed with these suggestions as guidelines for testing epidemiological patterns of enterococcal mastitis within a dairy herd during $6 \mathrm{mo}$. A similar survey of animals and environmental surfaces on poultry and swine farms also provided PFGE evidence of extreme genetic diversity among enterococci populations within a farm (Garcia-Migura et al., 2005).

Genetic heterogeneity of enterococci has been shown previously in food animals including poultry (GarciaMigura et al., 2005; Hershberger et al., 2005; Jackson, et al., 2006), swine (Garcia-Migura et al., 2005; Hershberger et al., 2005), beef, and dairy cattle (Hershberger et al., 2005). Clinical studies of enterococci from human urinary tract infections and intestinal flora found con-

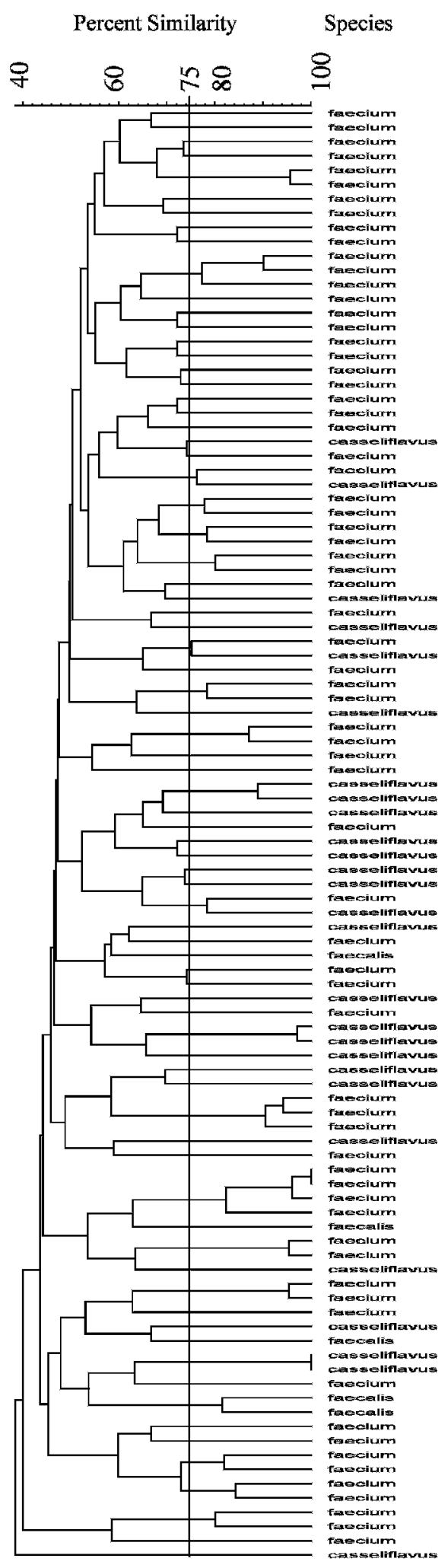

Origin

Poatparturn High 500 . Postpearturr High $\$ \subset 0$ Cillnical Mastrie Clinicieal Mastitis Posical Mastitio High sce High scic Bedding Hian sece High $5 \mathrm{co}$ High seco Hiah sec High scic Glinical Mastitio Hian secto Olinical Mastitis Glintionl Mastitio Hign sece Cliniosal Mastitis Badding High sece Clinical Mastitis High scC
High scc Glintiogl Mastitis Badding High sce Postpartum Beadding Bedaing High sicic Clinical Mastitis High $\$ C C$
Glinical Mastitio Postparturn High sec High sec
High sec Ciliniceal Mastitis High sec
High $\sec$ High 300 Beddings High sace Postpartu Bedding Cilnical Mastrtis Hist sing Cilnical Masttle High ace High soo High sec Bendaing High 560 High sec High sice Postpartum High 000 High 000
High 500 Bedding Bedding Feed

Fene

Feed Poetpartum Cillnical Mnastrtis Bodding Poestpartum Postparturn High Sce Fera High sec High sec Postpartum Clinical Mastitis Cllnioal Masstlts Postpartum Portpartums Elinical Mastitio High $50 \mathrm{C}$ High sece High sico Bredding

Figure 1. Dendrogram obtained by using pulsed field gel electrophoresis profiles for 102 strains of Enterococcus spp. isolates of bovine origin generated by the unweighted pair group algorithm with arithmetic averages. Isolate clusters were delineated with a 75\% similarity cut-off value, as indicated by the vertical line. 
Table 2. A description of 20 clusters observed when a 75\% similarity cut-off was applied to a dendrogram of 102 pulsed field gel electrophoresis patterns of Enterococcus spp. isolates of various sources ${ }^{1}$ of bovine origin

\begin{tabular}{|c|c|c|c|}
\hline Cluster & $\begin{array}{c}\text { Isolates, } \\
\mathrm{n}\end{array}$ & Source (n) & Species (n) \\
\hline E1 & 2 & $\begin{array}{l}\text { High SCC (1) } \\
\text { Clinical mastitis (1) }\end{array}$ & Enterococcus faecium (2) \\
\hline E2 & 2 & $\begin{array}{l}\text { High SCC (1) } \\
\text { Clinical mastitis (1) }\end{array}$ & E. faecium (2) \\
\hline E3 & 2 & $\begin{array}{l}\text { High SCC (1) } \\
\text { Postpartum (1) }\end{array}$ & $\begin{array}{l}\text { E. faecium }(1) \\
\text { Enterococcus casseliflavus }(1)\end{array}$ \\
\hline E4 & 2 & $\begin{array}{l}\text { High SCC (1) } \\
\text { Clinical mastitis (1) }\end{array}$ & E. faecium (2) \\
\hline E5 & 2 & High SCC (2) & E. faecium (2) \\
\hline E6 & 2 & High SCC (2) & E. casseliflavus (2) \\
\hline E7 & 2 & High SCC (2) & E. casseliflavus (2) \\
\hline E8 & 2 & Clinical mastitis (2) & E. faecium (2) \\
\hline E9 & 2 & Postpartum (2) & E. faecium (2) \\
\hline E10 & 2 & High SCC (2) & E. casseliflavus (2) \\
\hline E11 & 2 & $\begin{array}{l}\text { Postpartum (1) } \\
\text { Clinical mastitis (1) }\end{array}$ & E. faecalis (2) \\
\hline E12 & 2 & $\begin{array}{l}\text { Postpartum (1) } \\
\text { Clinical mastitis (1) }\end{array}$ & E. faecium (2) \\
\hline E13 & 2 & $\begin{array}{l}\text { Postpartum (1) } \\
\text { Clinical mastitis (1) }\end{array}$ & E. faecium (2) \\
\hline E14 & 2 & High SCC (2) & E. faecium (2) \\
\hline E15 & 3 & $\begin{array}{l}\text { High SCC (2) } \\
\text { Bedding (1) }\end{array}$ & E. faecium (3) \\
\hline E16 & 2 & $\begin{array}{l}\text { Clinical mastitis (1) } \\
\text { Bedding (1) }\end{array}$ & $\begin{array}{l}\text { E. faecium (1) } \\
\text { E. casseliflavus (1) }\end{array}$ \\
\hline E17 & 2 & $\begin{array}{l}\text { Clinical mastitis (1) } \\
\text { Bedding (1) }\end{array}$ & $\begin{array}{l}\text { E. faecium }(1) \\
\text { E. casseliflavus }(1)\end{array}$ \\
\hline E18 & 2 & $\begin{array}{l}\text { Clinical mastitis (1) } \\
\text { Bedding (1) }\end{array}$ & E. faecium (2) \\
\hline E19 & 3 & High SCC (3) & E. faecium (3) \\
\hline E20 & 4 & Feed & E. faecium (4) \\
\hline
\end{tabular}

${ }^{1}$ Isolates were from quarter-milk samples collected using aseptic technique from high-SCC milk within 2 wk after DHI testing (high SCC), mammary quarters with clinical mastitis before antibiotic therapy (clinical mastitis), cows within $3 \mathrm{~d}$ after parturition (postpartum), bedding, and feed.

siderable genetic heterogeneity, without a dominant clonal strain (Gikas et al., 2005; Nichol et al., 2006). In an earlier study, isolates originating from cheese, animals, and humans were analyzed (Vancanneyt et al., 2002). Human-derived clinical isolates clustered into 1 large genomic group with isolates of other sources. However, within the genomic grouping, distinct strain types were seen. These results suggest that clinical isolates may be more closely related to isolates of other sources than to other clinical isolates, even from the same hospital (Vancanneyt et al., 2002). A limited number of isolates from quarter-milk samples of a single herd in the current study were similarly associated to both other isolates from mammary glands and isolates from the environment.

A single genetic clone was not found to be responsible for the enterococcal isolations from the mammary glands or environment of the survey farm. Host-to-host contagious transfer of etiological agents can result in a single or relatively few clones comprising the isolates from infected hosts (Seong et al., 2004). In addition, large branching clusters of genetically related isolates, as reported in nosocomial outbreaks of enterococcal infections (Nichol et al., 2006), were not observed in the present survey. Seventeen of the 20 clusters contained only a pair of enterococcal isolates, 2 clusters comprised 3 isolates, and a single cluster had 4 isolates from 3 feed sample. Four clusters containing isolates of mammary origin comprised 2 isolates from different quarters of the same cow, suggesting within-udder transfer of bacteria between mammary glands of those cows. Isolates from feed did display genetic similarity with one another but did not cluster with either those of mammary origin or those from bedding. However, mammary isolates did cluster with other mammary isolates and bedding isolates. Isolates identified by the biochemical typing as $E$. faecium and E. casseliflavus were found in the both dried manure bedding and quarter-milk samples, concurring with the PFGE cluster analysis that similar isolates were in both the cows and environment.

In summary, these data suggest that the Enterococcus spp. isolated from a single herd comprised a heterogeneous, genetically diverse group of organisms. The genetic diversity among the collection of enterococcal isolates of bovine origin used in the current study provided further evidence for the characterization of these bacteria as environmental mastitis pathogens (NMC, 1999). Understanding the epidemiology of enterococci with regards to common farm management practices could lead to further knowledge regarding the control and transmission of these organisms.

\section{REFERENCES}

Baldassarri, L., L. Bertuccini, R. Creti, G. Orefici, G. Dicuonzo, G. Gherardi, M. Venditti, and R. DiRosa. 2005. Clonality among Enterococcus faecium clinical isolates. Microb. Drug Res. $2: 141-145$.

Douglas, V. L., S. G. Fenwick, D. U. Pfeiffer, N. B. Williamson, and C. W. Holmes. 2000. Genomic typing of Streptococcus uberis isolates from cases of mastitis, in New Zealand dairy cows, using pulsedfield gel electrophoresis. Vet. Microbiol. 75:27-41.

Garcia-Migura, L., E. Pleydell, S. Barnes, R. H. Davies, and E. Liebana. 2005. Characterization of vancomycin-resistant Enterococcus faecium isolates from broiler poultry and pig farms in England and Wales. J. Clin. Microbiol. 43:3283-3289.

Gikas, A., A. Christidou, E. Scoulica, P. Nikolaidis, A. Skoutelis, S. Levidiotou, S. Kartali, E. Maltezos, S. Metalidis, J. Kioumis, G. Haliotis, S. Dima, M. Roumbelaki, N. Papageorgiou, E. I. Kritsotakis, and Y. Tselentis. 2005. Epidemiology and molecular analysis of intestinal colonization by vancomycin-resistant enterococci in greek hospitals. J. Clin. Microbiol. 43:5796-5799.

Gonzalez, R. N., D. E. Jasper, N. C. Kronlund, T. B. Farver, J. S. Cullor, R. B. Bushnell, and J. D. Dellinger. 1990. Clinical mastitis in two California dairy herds participating in contagious mastitis control programs. J. Dairy Sci. 73:648-660.

Hershberger, E., S. F. Oprea, S. M. Donabedian, M. Perri, P. Bozigar, P. Bartlett, and M. J. Zervos. 2005. Epidemiology of antimicrobial resistance in enterococci of animal origin. J. Antimicrob. Chemother. 55:127-130. 
Hogan, J. S., K. L. Smith, K. H. Hoblet, P. S. Schoenberger, D. A. Todhunter, W. D. Hueston, D. E. Pritchard, G. L. Bowman, L. E. Heider, B. L. Brockett, and H. R. Conrad. 1989. Field survey of mastitis in low somatic cell count herds. J. Dairy Sci. 72:15471556.

Jackson, C. R., A. L. Debnam, G. E. Avellaneda, J. B. Barrett, and C. L. Hofacre. 2006. Effect of subtherapeutic antimicrobials on genetic diversity of Enterococcus faecium from chickens. Avian Dis. 50:115-119.

Mannu, L., A. Praba, E. Daga, R. Comunian, S. Zanetti, I. Dupre, and L. A. Sechi. 2003. Comparison of the incidence of virulence determinants and antibiotic resistance between Enterococcus faecium strains of dairy, animal, and clinical origin. Int. J. Food Microbiol. 88:291-304.

McDougall, S., T. J. Parkinson, M. Leyland, F. M. Anniss, and S. G. Fenwick. 2004. Duration of infection and strain variation in Streptococcus uberis isolated from cows' milk. J. Dairy Sci. 87:2062-2072.

Middleton, J. R., L. K. Fox, J. M. Gay, J. W. Tyler, and T. E. Besser. 2002. Use of pulsed-field gel electrophoresis for detecting differences in Staphylococcus aureus strain populations between dairy herds with different cattle importation practices. Epidemiol. Infect. 129:387-395.

Nichol, K. A., M. Sill, N. M. Laing, J. L. Johnson, D. J. Hoban, and G. G. Zhanel. 2006. Molecular epidemiology of urinary tract isolates of vancomycin-resistant Enterococcus faecium from North America. Int. J. Antimicrob. Agents 27:392-396.
NMC. 1999. Laboratory Handbook on Bovine Mastitis. Revised Edition. Natl. Mastitis Counc. Inc., Madison, WI.

Saeedi, B., A. Hallgren, J. Jonasson, L. E. Nilsson, H. Hanberger, and B. Isaksson. 2002. Modified pulsed-field gel electrophoresis protocol for typing of enterococci. APMIS 110:869-874.

Seong, C. N., E. S. Shim, S. M. Kim, and J. C. Yoo. 2004. Prevalence and characterization of vancomycin-resistant enterococci in chicken intestines and humans of Korea. Arch. Pharm. Res. 27:246-253.

Tenover, F. C., R. D. Arbeit, R. V. Goering, P. A. Mickelsen, B. E. Murray, D. H. Persing, and B. Swaminathan. 1995. Interpreting chromosomal DNA restriction patterns produced by pulsed-field gel electrophoresis: Criteria for bacterial strain typing. J. Clin. Microbiol. 33:2233-2239.

Todhunter, D. A., K. L. Smith, and J. S. Hogan. 1995. Environmental streptococcal intramammary infections of the bovine mammary gland. J. Dairy Sci. 78:2366-2374.

Vancanneyt, M., A. Lombardi, C. Andrighetto, E. Knijff, S. Torriani, K. J. Bjorkroth, C. M. Franz, M. R. Foulquie Moreno, H. Revets, L. De Vuyst, J. Swings, K. Kersters, F. Dellaglio, and W. H. Holzapfel. 2002. Intraspecies genomic groups in Enterococcus faecium and their correlation with origin and pathogenicity. Appl. Environ. Microbiol. 68:1381-1391.

Zadoks, R., W. van Leeuwen, H. Barkema, O. Sampimon, H. Verbrugh, Y. Schukken, and A. van Belkum. 2000. Application of pulsed-field gel electrophoresis and binary typing as tools in veterinary clinical microbiology and molecular epidemiologic analysis of bovine and human Staphylococcus aureus isolates. J. Clin. Microbiol. 38:1931-1939. 